\title{
Effect of chufa flour addition on characteristics of yoghurt quality
}

\section{Ovidiu Tița ${ }^{1}$, Cristina Popovici ${ }^{2}$, Loreta Tamošaitiené ${ }^{3}$, Vijole Bradauskiene ${ }^{3,4}$, Mihaela Adriana Tița ${ }^{1}$}

\author{
1 - Lucian Blaga University of Sibiu, Sibiu, Romania \\ 2 - Technical University of Moldova, Chisinau, Moldova \\ 3 - Klaipeda State University of Applied Sciences, Klaipeda, Lithuania \\ 4 - Kaunas University of Technologie, Food Institute, Kaunas, Lithuania
}

Keywords:

Yoghurt,

Chufa

Flour

Diacetyl

Quality

\section{Article history:}

Received 16.03.2020

Received in revised

form 26.08.2020

Accepted 30.09.2020

\section{Corresponding}

author:

Mihaela Adriana Tița

E-mail:

mihaela.tita@

ulbsibiu.ro

DOI: $10.24263 / 2304-$ 974X-2020-9-3-11

\section{Abstract}

Introduction. The purpose of the research is to determine the effect of the addition of chufa flour on the characteristics of yoghurt quality.

Materials and methods. The yoghurt has been prepared by respecting the classic technological process, with the difference that chufa (Cyperus esculentus) flour has been added in different proportions (sample ICO3-0.3\%, ICO5-0.5\%, ICO7-0.7\%). The yoghurt samples have been kept at a temperature of $2-4{ }^{\circ} \mathrm{C}$ for 15 days. Diacetyl has been determined by gas chromatography method, titratable acidity of yoghurt samples - by titration with $0.1 \mathrm{~N} \mathrm{NaOH}$ and syneresis - using the methodology of Barkallah.

Results and discussion. After the first day of storage, the diacetyl content is low in all the analyzed samples, but the ICO5 sample showed a higher diacetyl content of $6.5 \mu \mathrm{g} / \mathrm{g}$. After 15 days of storage, the diacetyl content increased in all samples analyzed, so so diacetyl content of control sample is $6.4 \mu \mathrm{g} / \mathrm{g}$, ICO $3-15 \mu \mathrm{g} / \mathrm{g}$, ICO5 - $16.2 \mu \mathrm{g} / \mathrm{g}$ and ICO $718.8 \mathrm{mg} / \mathrm{g}$. The high content of diacetyl is found in ICO7, which means that the addition of chufa flour has a positive effect for lactic acid bacteria used in the fermentation process. The acidity increases in all yoghurt samples analyzed from day 1 to day 15 . The control sample shows lower acidity values between 80 and 108 ${ }^{\circ} \mathrm{T}$, compared to the other samples, but the sample with a chufa flour in the proportion of $0.7 \%$ has acidity values between 87 and $125^{\circ} \mathrm{T}$, which indicates that the addition influences this characteristic analyzed. The highest removal of the serum was observed for control sampkle in 1 and 15 days, compared to the samples ICO3, ICO5 and ICO7. The ICO7 sample shows a lower syneresis, respectively on the first day of $9 \%$, and the on 15 th day of $32 \%$.

Conclusions. The addition of chufa flour improves the quality of yoghurt, which is of particular importance to the consumer in choosing these dairy products. 


\section{- Food Technology -}

\section{Introduction}

Consumption of yoghurt has several benefits for human health, such as protection against gastrointestinal upsets, enhanced digestion of lactose by maldigestion, decreased risk of cancer, lower blood cholesterol, improved immune response and help the body assimilate protein and calcium [2-4]. The demand for dairy products with functional properties leads to the promotion of added-value products: fermented dairy drinks, probiotic and other functional yoghurts, reduced-fat and enriched milk products and other [26]. Another important trend is the increasing demand for consumer convenience. Consumers prefer foods that promote good health and prevent diseases [27].

Many researchers have conducted studies on improving the composition of yoghurt by using it with milk proteins or vegetable proteins [5-8]. One of the ways to improve the nutritional value of yoghurt is to use the chufa (Cyperus esculentus). The chufa has been shown to have various beneficial health effects such as preventing obesity and lowering cholesterol and triglycerides. [9, 28] Its chemical composition includes fibre, protein and natural sugars. Moreover, chufa has a high content of soluble glucose and oleic acid, along with high energy content (starch, fats, sugars and proteins), are rich minerals such as phosphorous, potassium and in vitamins $\mathrm{E}$ and $\mathrm{C}$ [10]. The chufa flour can also be considered an excellent source of natural antioxidants (mainly flavonoids) and a natural food additive [11]. These numerous nutritional advantages and health benefits associated with chufa makes it more attractive for dairy products.

The sample of application of chufa flour in food technology is the production of "Horchata de chufa" ("tiger nut" or "chufa" milk), is a sweetened water extract of chufa tubers, which is popular in Spain [29]. Adgidzi et al. [30] investigated yoghurt-like products from chufa. The use of chufa and cow milk composite to prepare yoghurt reduces the cost of yoghurt production without compromising its nutritional composition and therapeutic effects. It is possible to manufacture probiotic yoghurt using chufa extract as a functional dairy food [31]. A product known as cypher-coconut yoghurt can be prepared using coconut milk blended with chufa milk, and the commercially available starter used as a source of lactic acid bacteria [32]. It is also used as a flavouring agent in ice cream [33]. Ice cream production from a blend of chufa and cow milk was subjected to proximate, physicochemical and sensory evaluation by Umelo et al [33]. Flour of roasted chufa is sometimes added to bakery products [34], as well as in making oil, starch extracts and soap [35].

However, it's not enough nutritional advantages and health benefits of the product for successful commercial promotion, and it's necessary to supply good sensory properties of new a product. Generally lactic acid gives fermented milk their slightly tart taste. Other typical flavours and aromas are additional results of LAB metabolism [36]. Thus, more than 100 chemical compounds was isolated from yoghurt and other fermented milk, but only a few (ethanol, diacetyl, acetaldehyde, acetone and butanone-2) influence on the desired product flavour $[37,38,39]$.

Acetaldehyde provides the typical aroma of yoghurt [25]. The Streptococcus may form acetaldehyde from lactose via pyruvate, but only trace amounts are formed by this way and by Lactobacillus delbrueckii subsp. bulgaricus. Optimum aroma and flavour are obtained between 23 and $41 \mathrm{ppm}$ acetaldehyde. Diacetyl and acetoin result from the metabolic activity of Streptococcus thermophilus are very low $-0.5 \mathrm{ppm}$. Diacetyl is produced by Lactococcus lactis subsp. lactis biovar. diacetylactis and Lactococcus lactis subsp. cremoris. The presence of diacetyl contributes to the delicate, full flavour and aroma of yoghurt and is especially important, if acetaldehyde is low because it can enhance yoghurt flavour [25]. 
Note, in the available scientific literature there are insufficient data about the effect of the addition of chufa flour on the characteristics of yoghurt quality.

Therefore, the purpose of the research is to determine the effect of the addition of chufa flour on the characteristics of yoghurt quality. Also, an important task is to study the degree of syneresis in the product to ensure uniform consistency during storage.

\section{Materials and methods}

\subsection{Materials and sample preparation}

For yoghurt preparation, cow milk has been used. Used milk has a fat content of $1.5 \%$ because it takes into account the consumer's preference to consume dairy products with lowfat content [12, 13].

The technological scheme is identical to the classic one concerning the technological parameters [14]. For inoculation, a specific culture for the processing of yoghurt from CHR HANSEN has been used in the proportion of $0.075 \mathrm{~g} / \mathrm{L}$ milk [15].

Different percentage of chufa (Cyperus esculentus) flour has been added before homogenization, in the following proportions: $0.3 \%, 0.5 \%$ and $0.7 \%$, and the mixture obtained has been packed in glass jars with lids, placed under thermostat at a temperature of $42{ }^{\circ} \mathrm{C}$ for 3.5 hours and cooled to $20{ }^{\circ} \mathrm{C}$ for one hour. Yoghurt has been stored at a refrigeration temperature of $2-4{ }^{\circ} \mathrm{C}$ [16].

The yoghurt samples have been analyzed after two storage periods 1 day (T1) and 15 days (T15) at $4{ }^{\circ} \mathrm{C}$.

The analyzed samples were marked as follows:

1.Control sample, yogurt with $1.5 \%$ fat: IM;

2.Yoghurt with a chufa flour addition of $0.3 \%$ : IC03;

3.Yoghurt with a chufa flour addition of $0.5 \%$ : IC05;

4. Yoghurt with a chufa flour addition of $0.7 \%$ : IC07.

\subsection{Methods of analysis}

\subsubsection{Preparation of samples for GLC analysis}

Diacetyl extraction has been performed using high purity acetone. Approximately $2 \mathrm{~g}$ of the sample has been accurately weighed, $2 \mathrm{~mL}$ of acetone and $2 \mathrm{~mL}$ of 2,3-pentandione of $50 \mu \mathrm{g} / \mathrm{mL}$ were added as internal standard and stirred vigorously for 30 seconds. After the samples were centrifuged at $4000 \mathrm{rpm}$ for 5 minutes, the supernatant has been filtered through a $0.20 \mu \mathrm{m}$ disposable syringe membrane filter and then injected directly into the gas chromatography apparatus. The final diacetyl concentration (expressed as $\mu \mathrm{g}$ of diacetyl per gram of sample) has been calculated using the following formula [11]:

$$
\text { Diacetyl }(\mu \mathrm{g} / \mathrm{g})=\frac{w I S \cdot A D \cdot P \cdot 0,5}{A I S \cdot W S \cdot 25}
$$


where:

$\mathrm{W}_{\mathrm{IS}}$ - internal standard (2.3 pentanedione), $\mu \mathrm{g}$;

$\mathrm{A}_{\mathrm{D}}$ - diacetyl peak area;

$\mathrm{A}_{\mathrm{IS}}$ - the peak area of the internal standard;

$\mathrm{W}_{\mathrm{s}}$ - sample table, g;

$\mathrm{P}$ - purity of the standard, \%;

0,5 - dilution factor;

25 - dilution factor.

\subsubsection{Gas-chromatographic analysis}

Diacetyl gas chromatographic analysis has been performed by manual injection using an Agilent Technologies Model 7890A gas chromatograph equipped with a flame ionization detector. A sequence has been created using Chem Station software to analyze the samples and quantify the results.

A 30 m YB WAX capillary column (Phenomenex, Torrance, CA.USA) with a diameter of $0.32 \mathrm{~mm}$, a particle size of $0.5 \mu \mathrm{m}$ and a composition of $100 \%$ polyethylene glycol has been used. The following parameters have been used for the analysis:

- Carrier gas, a combination of nitrogen and hydrogen at a flow rate of $50 \mathrm{kPa}$ (7.25 psi);

- Injection volume: $1 \mu \mathrm{l}$

- Injection ratio at injection, $1: 15$;

- Injector temperature: $250{ }^{\circ} \mathrm{C}$;

- Detector temperature: $260^{\circ} \mathrm{C}$;

- The oven temperature increases progressively by $7{ }^{\circ} \mathrm{C} / \mathrm{min}$ from $50{ }^{\circ} \mathrm{C}$ to $240{ }^{\circ} \mathrm{C}$.

The diacetyl peak recognition has been performed by comparing its retention time with that of the relative standard. The quantitative measurement of diacetyl has been calculated from the diacetyl peak area compared with that of the 2,3-pentanedione. Some samples of the gas chromatography profiles for yoghurts enriched with chufa are presented in Figures 1 and 2:

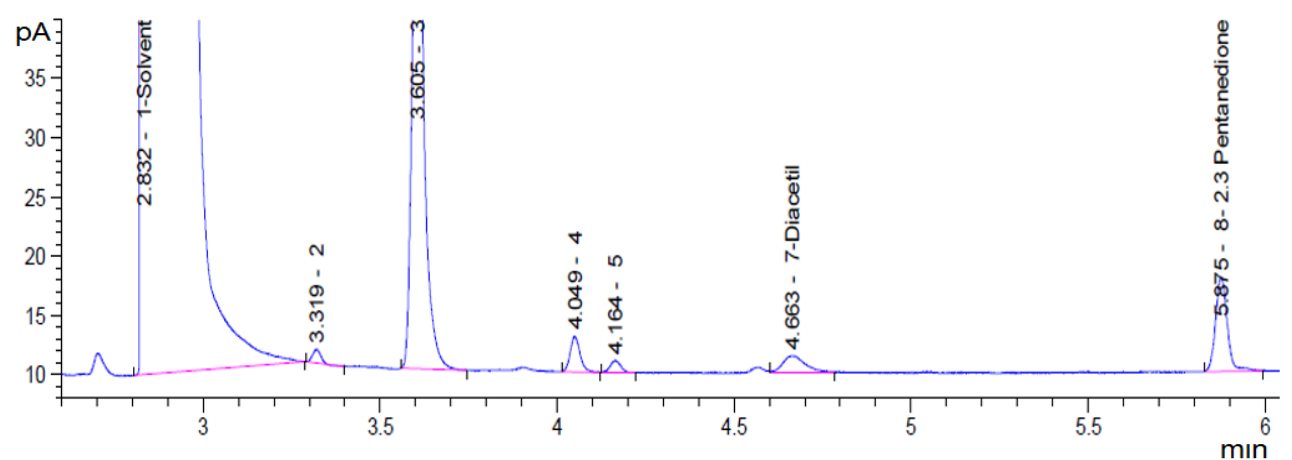

Figure 1. GC chromatogram of yoghurt with $0.3 \%$ chufa (T1): 1-Solvent; 2, 3, 4, 5-Solvent impurities; 6-Yoghurt component; 7-Diacetyl; 8-Internal standard 2.3 Pentanedione 


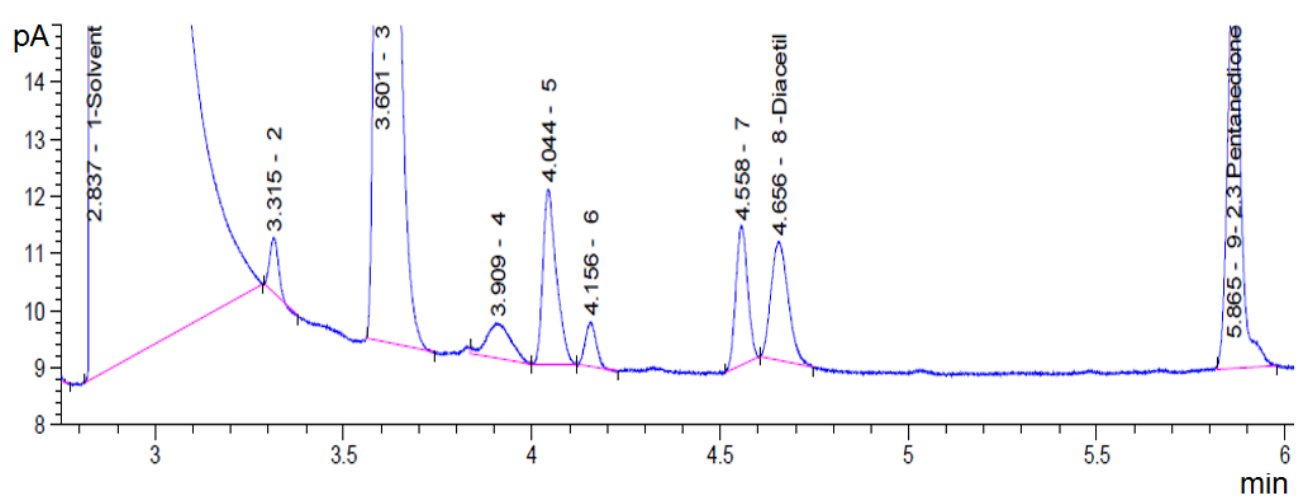

Figure 2. Gc Chromatogram of Yoghurt with chufa $0.7 \%$ (T15):

1-Solvent; 2,3,5,6-Solvent impurities; 4,7-Yoghurt components;

8-Diacetyl; 9-Internal standard 2.3 Pentanedione

\subsubsection{Titrable Acidity}

Titrable acidity of yoghurt samples has been determined by titration with $\mathrm{NaOH} 0.1 \mathrm{~N}$ solution using phenolphthalein as an indicator and expressed in Thörner degrees [20].

\subsubsection{Susceptibility to Syneresis}

Syneresis of the different yoghurt samples has been determined according to the methodology proposed by Barkallah et al [21] by placing $100 \mathrm{~mL}$ of each sample in a funnel lined with Whatman filter paper number 1 . After $6 \mathrm{~h}$ of drainage, the volume of whey has been measured and the following formula has been used to calculate susceptibility of syneresis:

where,

$$
\text { Syneresis }=\frac{V_{1}}{V_{2}} \cdot 100
$$

$\mathrm{V}_{1}=$ volume of whey collected after draining, $\mathrm{ml}$;

$\mathrm{V}_{2}=$ the volume of the yoghurt sample, $\mathrm{ml}$;

\section{Results and discussions}

\subsection{Determination of diacetyl}

Figure 3 shows the results obtained for the determination of diacetyl of the samples obtained during the analyzed period. 


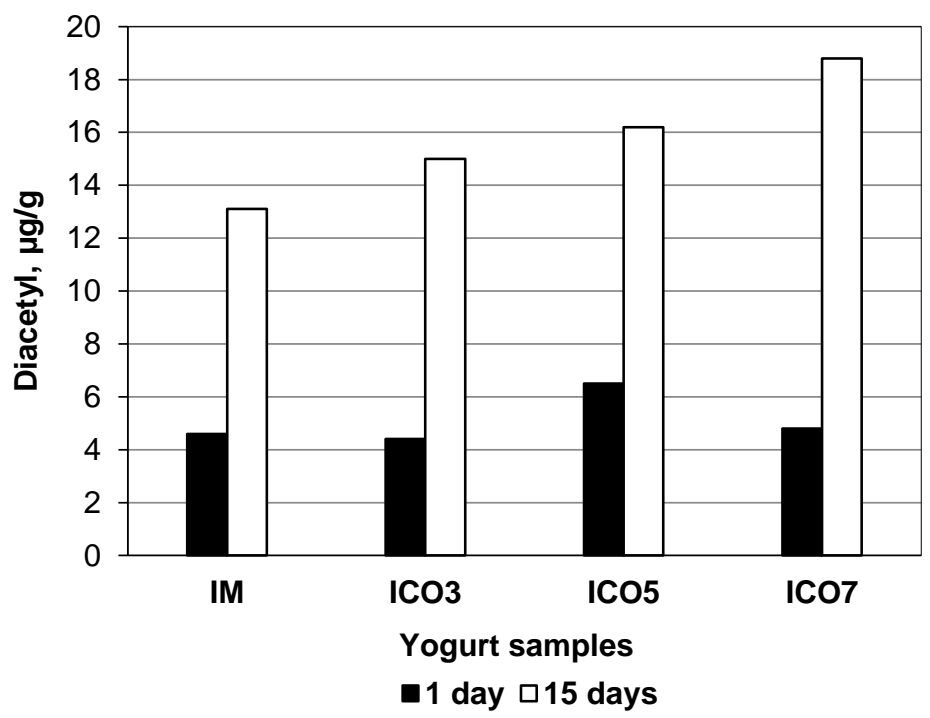

Figure 3. Evolution of diacetyl content in yoghurt samples

The diacetyl content analyzed in 1 day shows different values, so the control sample, the sample with an addition of 0.3 and the sample with $0.7 \%$ chufa between 4.4 and $4.8 \mu \mathrm{g} / \mathrm{g}$, and the sample with a chufa of 0.5 has a content higher than $6.5 \mu \mathrm{g} / \mathrm{g}$.

After 15 days of storage, the diacetyl content of the samples increased considerably, so the control sample has a value of $13.1 \mu \mathrm{g} / \mathrm{g}$, and the sample with $0.7 \%$ chufa has the highest diacetyl content of $18.8 \mu \mathrm{g} / \mathrm{g}$ compared to the samples by $0.3 \%(15 \mu \mathrm{g} / \mathrm{g})$ and the sample by $0.5 \%(\mu \mathrm{g} / \mathrm{g})$.

The results of diacetyl content during storage are in agreement with Vahcic and Hruskar (2000) [25], in which diacetyl was found to increase slightly almost linearly on the lowest temperature $\left(4{ }^{\circ} \mathrm{C}\right)$, but significantly on higher temperature levels $\left(20\right.$ and $\left.37^{\circ} \mathrm{C}\right)$ during 25 days of storage (Figure 4 [25]). Our obtained higher levels of diacetyl may be explained by the adding of chufa, which components may enhance the production of diacetyl by starter organisms.

El-Shenawy et al. (2012) [31] studied the diacetyl content of probiotic yoghurt made with chufa extract, stored at $4 \pm 2{ }^{\circ} \mathrm{C}$ for 10 days. It was observed a gradual increase in the concentration of diacetyl until day 10 , that is similar to our results. However, the initial diacetyl content of our samples is lower than obtained results by El-Shenawy et al [31]. This may be due to the different composition of the starter microorganisms. It is well known, that different starter microorganisms influence the flavour as well as the texture of the final product $[25,36]$. 


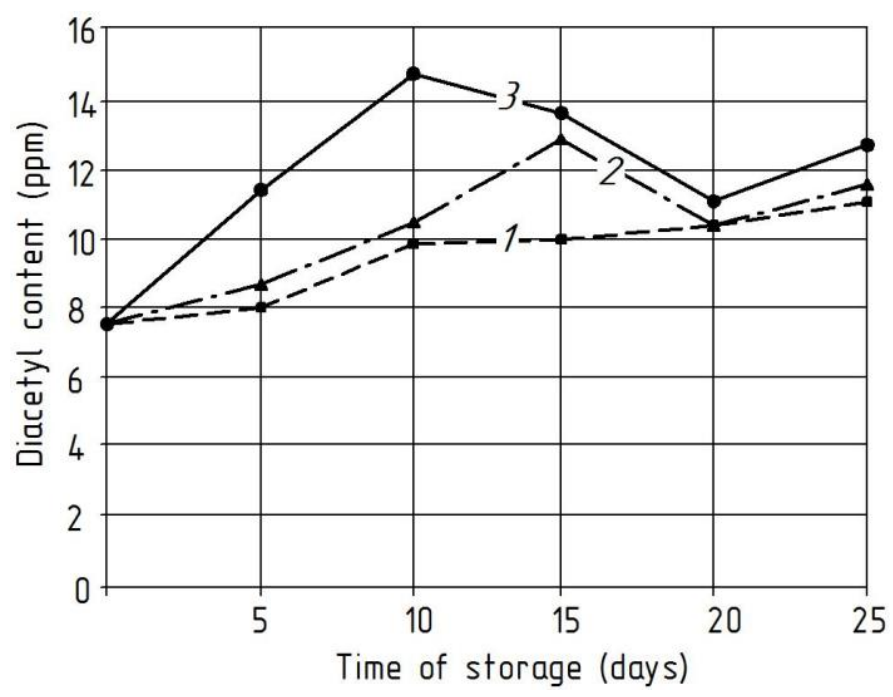

Figure 4. Diacetyl content in samples during storage [25].

Temperature: $1-4{ }^{\circ} \mathrm{C} ; 2-20{ }^{\circ} \mathrm{C} ; 3-37^{\circ} \mathrm{C}$.

\subsection{Determination of acidity}

The acidity of a food product is one of the first quality indices that demonstrate its freshness [22]. The results obtained for the determination of the acidity of the analyzed yoghurt samples are presented in Figure 5.

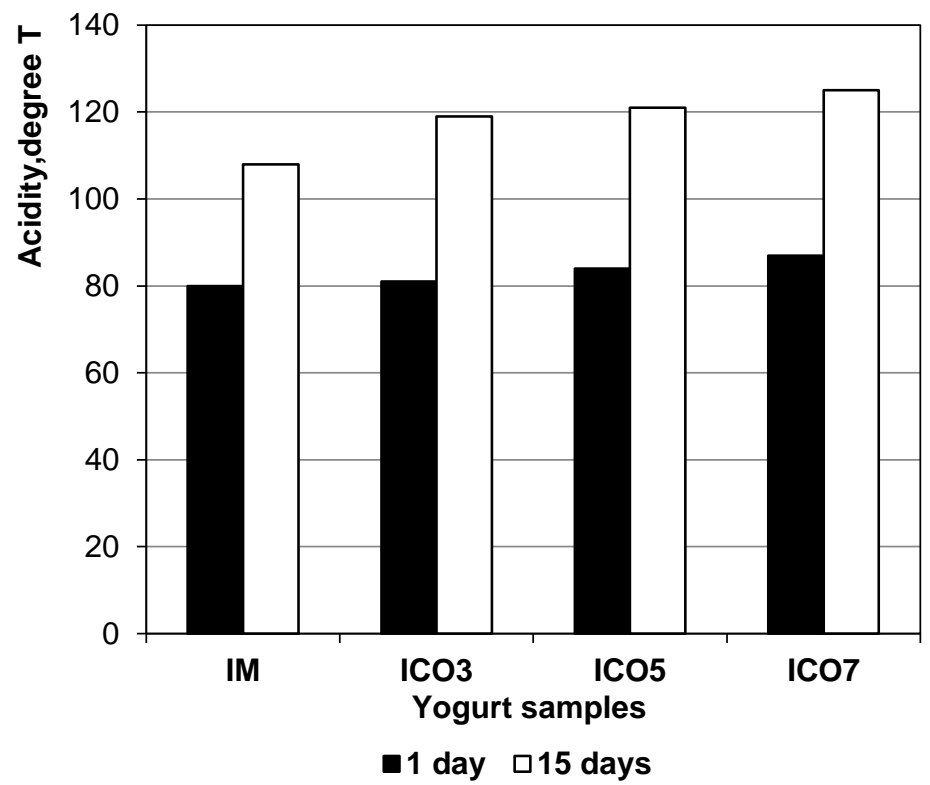

Figure 5. The evolution of the acidity of yoghurt samples 
Following the determination, an increase in acidity is observed in all yoghurt samples, from day 1 to day 15 . The IM sample shows acidity values between $80^{\circ} \mathrm{T}$ and $108^{\circ} \mathrm{T}$. In the case of samples IC03, IC05 and ICO7, the addition of chufa flour contribute to the variation of the titratable acidity, the values being between 81,84 and $87^{\circ} \mathrm{T}$ on day 1 and 119,121 and $125^{\circ} \mathrm{T}$ for day 15 . The evolution of the acidity for the samples with the addition of the chufa is higher than the control sample, and the sample with the highest quantity of the chufa, respectively of $0.7 \%$ presents the highest acidity for the analyzed period.

One explanation for this is that the chufa used improves the growth of bacteria contained in yoghurt samples. This increase of lactic acid bacteria may be due to the presence of some growth promoter, such as salts, free amino acids, or vitamins present in chufa [40]. Also, it has been found, that starch and fibre content of chufa presumably provides prebiotic properties for colon bacteria, as well as, yoghurt microorganisms [41]. Ire F.S., Maduka N. and Njoku H.O (2017) [42] reported that chufa milk was a possible culture medium to cultivate probiotic lactic acid bacteria such as Lactobacillus plantarum, Lactobacillus acidophilus, Streptococcus thermophilus and Lactobacillus brevis.

A similar observation was reported by [21], who reported that the acidity of the yoghurt increased due to the type of added plants. R.E.Sanful (2009) [43] obtained similar results during the investigation of chufa, cow milk and their compositions as substrates for yoghurt production.

\subsection{Determination of syneresis}

Syneresis is considered by many researchers as one of the most important parameters that indicate the quality of yoghurt during storage [23]. The following figure shows the changes in the syneresis rates of the yoghurt samples analyzed during the storage period.

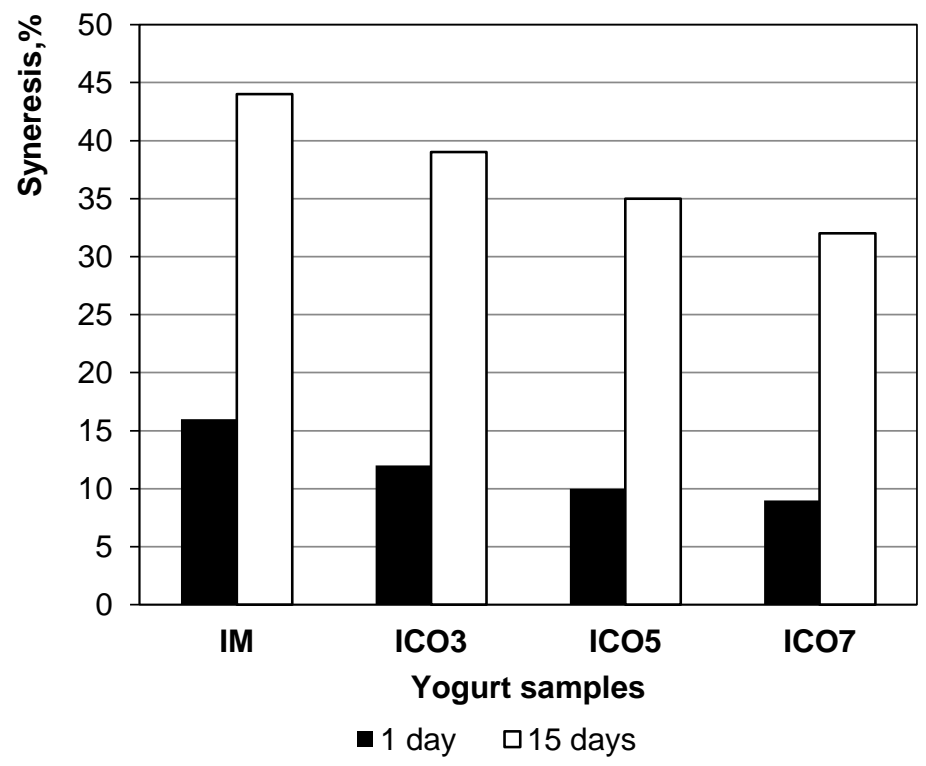

Figure 9. The evolution of the syneresis of yoghurt samples 


\section{Food Technology}

The control sample showed a higher syneresis compared to the yoghurt samples with different levels of added chufa so that after 15 days of storage it shows elimination of whey of $44 \%$ because the dry matter content also has an influence.

In the case of samples IC03, IC05 and ICO7, the addition of chufa contribute to the syneresis process, the values being between 12, 10 and $9 \%$ respectively on day 1 and 39, 35 and $32 \%$ for day 15 . The lowest syneresis after 15 days of storage was observed for chufa yoghurt with an addition of $0.7 \%$, which demonstrates that the addition of chufa flour improves the texture of the yoghurt, and thus reduces the process of syneresis. And for this studied feature there is a similar observation which shows that syneresis is influenced by the amount of additive used [24].

The ability of yoghurt to retain whey depends on structure and pore size of protein gel [44]. Its appears that supplementation with a low level of chufa may contain some polysaccharides which enhance the water holding capacity, while supplementation with the high level impaired the yoghurt structure, thereby decreased whey syneresis. Folkenberg et al. (2006) [45] observed that syneresis was more pronounced in EPS containing yoghurts. They have suggested that yoghurts should have a structure with medium size pores containing polysaccharides to provide a stable structure with minimum syneresis. A similar observation during storage was made by Doleyres et al. (2005) [46] in yoghurts prepared using EPSproducing cultures, as well as, El-Shenawy et al. (2012) [31] in yoghurts with chufa extracts.

\section{Conclusions}

1. The characteristics of the yoghurt quality with the addition of a chufa flour were improved compared to the control sample.

2. The use of a larger amount of chufa positively influenced the parameters analyzed during storage.

3. The addition of chufa shows that it improves the quality of the yoghurt and implicitly the requirements of the consumers.

\section{References}

1. Ozturkoglu-Budak, S., Akal, C., Yetisemiyen, A. (2016), Effect of dried nut fortification on functional, physicochemical, textural, and microbiological properties of yogurt, Journal of Dairy Science, 99(11), pp. 8511-8523

2. Marona, D. and G. Pedrigon, (2004),Yoghurt feeding inhibits promotion and progression of cancer, MedSciMonit, 10(4), pp. 96-104.

3. Perdigeon, G., J. Valdez and M. Rachid,(1998), Antitumour activity of yoghurt. Study of possible immune response, Journal of Dairy Research, 65(1), pp. 129-138.

4. Salwa, A. Aly. E.A. Galal. Neimat, A. Elewa, (2004), Carrot Yoghurt: Sensory, Chemical, Microbiological Properties and Consumer Acceptance, Pakistan Journal of Nutrition, 3(6), pp. 322-330.

5. Lobato-Callerosa, C., Martínez-Torrijosa, O., Sandoval-Castillaa, O., Pérez-Orozcob, J.P., Vernon-Carter, E.J., (2004), Flow and creep compliance properties of reducedfat yoghurts containing protein-based fat replacers, International Dairy Journal, 14, pp. 777-782. 
6. Sandoval-Castillaa, O., Lobato-Callerosa, C., Aguirre-Mandujanoa, E., VernonCarter, E.J., (2004), Microstructure and texture of yogurt as influenced by fat replacers, International Dairy Journal, 14, pp. 151-159.

7. Yazici, F., Akgun., A.., (2004), Effect of some protein based fat replacers on physical, chemical, textural, and sensory properties of strained yoghurt, Journal of Food Engineering, 62, pp. 245-254.

8. Akalin, A.S., Unal, G., Dinkci, N., Hayaloglu, A.A.., (2012), Microstructural, textural, and sensory characteristics of probiotic yogurts fortified with sodium calcium caseinate or whey protein concentrate, Journal of Dairy Science, 95, pp. 3617-3628.

9. Mi Kyung Moon, Jiyun Ahn, Hyunyu Lee \& Tae Youl Ha., (2012), Anti-obesity and hypolipidemic effects of chufa in mice fed a high-fat diet, Food Science and Biotechnology, 21, pp. 317-322.

10. Ozcan M. M., Gumuscu F. Er, Arslan D., Ozkalp B. (2010), Chemical and fatty acid composition of Cyperus esculentus, Chemistry of Natural Compounds, p. 233.

11. Yanghe Luo, Xingren Li, Juan Heb, Jia Su, Liyan Peng, Xingde Wu, Runan Du, Qinshi Zhao (2014), Isolation, characterisation, and antioxidant activities of flavonoids from chufa peels, Food Chemistry, 164, pp. 30-35.

12. Machin D.R., Park W., Alkatan M., Mouton M., Tanaka H. (2015), Effects of non-fat dairy products added to the routine diet onvascular function: A randomized controlled crossover trial, Nutrition, Metabolism \& Cardiovascular Diseases, 25, pp. 364-369.

13. Kris-Etherton P.M., Krauss R.M, (2020), Public health guidelines should recommend reducing saturated fat consumption as much as possible: YES, The American journal of clinical nutrition, 112(1), pp. 13-18.

14. Costin G.M., (2015), Produse lactate fermentate, Departamentul de Știință și Ingineria Laptelui, Universitatea "Dunărea de Jos", Galați.

15. Arioli S., Scala G.D., Remagni M.C., Stuknyte M., Colombo S., Guglielmetti S., De Noni I., Ragg E., Mora D. (2017), Streptococcus thermophilusurease activity boosts Lactobacillus delbrueckii subsp.bulgaricushomolactic fermentation, International Journal of Food Microbiology, 247, pp. 55-64.

16. Banu C., Vizireanu C. (1998), Procesarea industrială a laptelui, Editura Tehnică, Bucuresti.

17. Antonella De Leonardis, Francesco Lopez, Ahindra Nag, Vincenzo Macciola, (2013), Occurrence and persistence of diacetyl in unfermented and fermented milks, European Food Research and Technology, 236, pp. 691-697.

18. Macciola V., Candela G., De Leonardis, A., (2008), Rapid gas-chromatographic method for the determination of diacetyl in milk,fermented milk and butter, Food Control, 19, pp. 873-878.

19. Muntean D. L., Bojiţă M., (2014), Cromatografie în faza gazoasă. În D. L. Muntean, \& M. Bojiţă, Controlul medicamentelor, Metode spectrale, cromatografice şi electroforetice de analiză, Editura Medicală Universitară "Iuliu Haţieganu", Cluj Napoca, pp. 253-263.

20. Tița Mihaela-Adriana, (2002), Manual de analiza și controlul calităţii în industria laptelui, Editura universității "Lucian Blaga", Sibiu.

21. Barkallah M., Dammak M., Louati I., Hadrich B., Mechichi T., Ayadi M., Abdelkafi S. (2017), Effect of Spirulina platensis fortification on physicochemical, textural, antioxidant and sensory properties of yogurt during fermentation and storage, LWT Food Science and Technology, pp. 323-330.

22. Masulli D., (2016), Measuring $\mathrm{pH}$ and titrable acidity of yogurt, Food Quality \& Safety, 4, pp. 651-662. 


\section{Food Technology}

23. Özge Dönmez, Burçe Ataç Mogol, and Vural Gökmen, (2017), Syneresis and rheological behaviors of set yogurt containing green tea and green coffee powders, $J$. Dairy Sci., 100, pp. 901-907.

24. Staffolo M., Bertola N., Martino M., Bevilacqua A., (2004), Influence of dietary fiber addition on sensory and rheological properties of yogurt, International Dairy Journal, 14(3), pp. 263-268.

25. Vahcic N., Hruskar M. (2000). Slovenian fermented milk with probiotics, Zb Biotehniske fak Univ v Ljubljani Kmetijstvo Zootehnika, 76, pp. 41-46, Available at: http://aas.bf.uni-lj.si/zootehnika/76-2000/PDF/76-2000-2-41-46.pdf

26. Rudrello F. (2004), Health trends shape innovation for diary products (online), Euromonitor Anternational Available at: http://www.euromonitor.com/article.asp?id=401.

27. Khurana H.K., Kanawjia S.K. (2007), Recent trends in development of fermented milks, Curr. Nutri Food Sci., 3, pp. 91-108.

28. Ire F.S, Maduka N., Njoku H.O. (2017), Effect of Natural Flavouring Agents and Storage Conditions on Physicochemical Properties and Viability of Probiotic Lactic Acid Bacteria Incorporated into Chufa-Milk Drink, Curr Trends Biomedical Eng \& Biosci, 4(4), 555643.

29. Mosquera L.A., Sims C.A., Bates R.P., O'Keefe S.F (1996), Flavor and stability of 'horchata de chufas', J Food Sci, 61(4), pp. 856-861.

30. Adgidzi E.A., Ingbian E.K., Abu J.O. (2011), Effects of storage on the quality of chufa (Cyperusesculentus) products, Product Agric, Tech., 7(1), pp. 131-147.

31. El-Shenawy M., Abd El-Aziz M., El-kholy W.I., Fouad M.T. (2012), Probiotic yoghurt manufactured with tiger-nut extract (Cyperus esculentus) as a functional dairy food, J. Agric. Res., Nat. Res., 1(2), pp. 20-31.

32. Belewu M.A., Belewu K.Y., Bamidele R.A. (2010), Cyper-coconut yoghurt: Preparation, compositional and orgaanoleptic qualities, Afri. J. Food Sci. Tech., 1(1), pp. 010-012.

33. Umelo M.C., Uzoukwu A.E., Odimegwu E.N., Agunwah I.M., Njoku N.E., Alagbaoso S.O. (2014), Proximate, physicochemical and sensory evaluation of ice cream from blends of cow milk and chufa (Cyperus esculentus) milk, Int. J. Sci. Res. Innov. Tech., 1(4), pp. 63-76.

34. Coşkuner Y., Ercan R., Karababa E., Nazlican A.N. (2002), Physical and chemical properties of chufa (Cyperus esculentus L) tubers grown in the Cukurova region of Turkey, J. Sci. Food. Agri., 82, pp. 625-631.

35. Adejuyitan J.A. (2011), Chufa processing: its food uses and health benefits, Am. J. Food. Technol., 6(3), pp. 197-201.

36. (2007), Yoghurt: Science and Technology, 3rd ed. by A Y Tamime and R K Robinson, Woodhead Publishing, Cambridge.

37. Ulberth F. (1991), Headspace gas chromatographic estimation of some yogurt volatiles, Journal of Association of Official Analitycal Chemists, 74, pp. 630-634.

38. Kneifel W., Ulberth F., Erhard F.,Jaros D. (1992), Aroma profiles and sensory properties of yogurt and yogurt-related products, I. Screening of commercially available starter cultures. Milchwissenschaft, 47(1992), pp. 362-365.

39. Ulberth F., Kneifel W. (1992), Aroma profiles and sensory properties of yogurt and yogurt-related products. II. Classification of starter cultures by means of cluster analysis, Milchwissenschaft, 47(1992), pp. 432-434.

40. Mason D. (2008), Chufas, National vegetable society, Available at: http: /www.nvsuk.org. uk/growing_show_vegetables 1/ Chufa. Ph.D. 
41. Alegría-Torán and Farré-Rovira (2003), Horchata y salud: Aspectos nutricionales y dietéticos. In: Fundación Valenciana de Estudios Avanzados, editor. Jornada Chufa y Horchata: Tradición y Salud, Conselleńa de Agricultura, Pesca y AlimentaciónValencia, pp. 55-70.

42. Ire F.S, Maduka N., Njoku H.O (2017), Effect of Natural Flavouring Agents and Storage Conditions on Physicochemical Properties and Viability of Probiotic Lactic Acid Bacteria Incorporated into Chufa-Milk Drink, Curr Trends Biomedical Eng \& Biosci., 4(4), pp. 555643.

43. Sanful R.E. (2009), The use of chufa (Cyperus esculentus), cow milk and their composite as substrates for yoghurt production, Pak.J. Nutri., 8(6), pp. 755-758.

44. Rybak O. (2014), The role of milk proteins in the structure formation of dairy products, Ukrainian Food Journal, 3(3), pp. 350-360.

45. Folkenberg D.M., Dejmek P., Skriver A., Guldager H.S., Ipsen R. (2006). Sensory and rheological screening of exopolysaccharide producing strains of bacterial yogurt cultures, Int. Dairy J., 16, pp. 111-118.

46. Doleyres Y., Schaub L., Lacroix C. (2005), Comparison of the functionality of exopolysaccharides produced in situ or added as bioingredients on yogurt properties, J. Dairy Sci., 88, pp. 4146-4156. 